\title{
The Research on the Efficiency of the Methods of Talent Management within Organizations
}

DOI: 10.15804/tner.2018.52.2.02

\begin{abstract}
The study presents the results of research based on the review and identification of significant talent management methods used in different types of organizations. The study interprets the results of research conducted in 2016 on the set of 301 various companies operating in the Czech Republic. The authors of the study assume that the efficiency of the whole talent management should be based on the efficiency of its well-chosen methods. The research showed that there is a different understanding and application of talent management methods by organization management according to the size and legal form of the organization (company).
\end{abstract}

Keywords: talent management, efficiency of methods, large organizations, small organizations, adult education, identification of talents, development of talents, retention of talents

\section{Introduction}

First we need to make clear what is the relationship of efficiency of different methods ${ }^{1}$ of talent management and efficiency of the entire talent management. It is very important to realize that talent management alone could not exist without

1 The efficiency of the method means the ratio of all costs and inputs required for the use of a particular method, and all the benefits and outputs that a particular method achieves. 
its processes and thus not without its methods. It is, therefore, misleading to talk about talent management without its components and it would be an empty concept. We will, therefore, assume that talent management is a set of activities, processes, tools and methods applied in the management of talented individuals in the organization. Under this assumption, we will consider the efficiency of talent management as a synergy effect of all of its elements. The efficiency of talent management is, therefore, a result of the effects of talent management efforts, both tangible and intangible, effects of using methods of talent management in individual processes (identification, development and retention of talents) and their related activities. Concepts of talent management and their problems can be also semi-finished by a lot of authors, e.g., Lewis, \& Heckman (2006); Swailes (2016); McDonnell, Collings, Mellahi, \& Schuler (2017) and Khoreva, Vaiman, \& Van Zalk (2017).

Hatum (2010, p. 15) claims that "there is no single blueprint for effective talent management". However, we dare to say that to be talent management effective, the cumulative effects of all its components must be observable and demonstrable in the positive result. Hatum (2010, p. 129) points out that inconsistency in talent management programs result is contrary to risks efficiency of their methods, staff frustration and talented individuals frustration.

To be able to objectively evaluate the performance of entire talent management, we should first dismantle the efficiency of all its components and consolidate their effects. Analysis of all components are beyond the scope of this study, therefore we focus only on the efficiency of methods of talent management, divided according to Kursch (2016a, p. 168). Over the efficiency of the whole program of talent management, we will consider only the total of the effects of its methods, and eliminate other influences, therefore assume no effects unrelated to their own methods and applications.

The research goal was to explore if methods perceived as effective for talent management are related to their frequent use in organizations, then which methods are considered most effective and whether efficiency is measured or not.

\section{Research problem and questions}

We started with the proposition that the efficiency of talent management depends on the efficiency of its methods. We considered identification, development and retention of talented people as base methods. From our foundations, the following research problem is derived: 
- P: How is the efficiency of talent management methods perceived in organizations of different types and sizes?

This research problem includes the following research questions:

- Q1: What methods do organizations consider as effective? (large-small, private-public) (related hypothesis: $\mathrm{H1}$ ).

- Q2: Which methods are, according to organizations, most efficient for the identification of talents? (large-small, private-public), (related hypothesis: $\mathrm{H} 2$ ).

- Q3: Which methods are, according to organizations, most efficient for the development of talents? (large-small, private-public) (related hypothesis: H3).

- Q4: Which methods are, according to organizations, most efficient for the retention of talents? (large-small, private-public) (related hypothesis: H4, H5).

- Q5: Is the efficiency of talent management measured? (large-small, private-public).

\section{Hypotheses $^{2}$}

- H1: Methods that are used in organizations most often are also reported to be the most effective ones.

- H2: Private organizations consider an interview with experts as a more effective method for identification of talents than public organizations.

- H3: Large private organizations, contrary to small organizations, consider several methods based on individual development (coaching, mentoring, counselling, assistance, job rotation, individual development plan) as the most effective methods of developing talents.

- H4: Public organizations consider methods for the retention of talents on the basis of non-financial benefits as more effective than private organizations.

- H5: With the larger size of private organizations, the indicated efficiency of financial valuation decreases.

2 These five hypotheses make up only a part of the complete research, where twenty-two hypotheses were tested, so the research questions were appropriately sourced by research hypotheses and we could make objective conclusions. 


\section{Research Sample}

The sample was selected from the population of all organizations that have more than 5 employees and their headquarters in the Czech Republic. Population ${ }^{3}$ is, therefore, all the organizations in the Czech Republic with more than 5 employees. The research tool was a carefully prepared questionnaire. We could not count on $100 \%$ returnability. If we want to reach an organization randomly, returned results will be in a small number (it can be assumed to be less than 20\%) and heavily dependent on self-selection, i.e., the decision to answer or not. In our research, we focus primarily on organizations using talent management and its methods, thus self-selection here will not play a major role in distorting. The resulting parameters of the sample are summarized in Table 1.

Furthermore, the comparison of representativeness of the sample was conducted on the basis of the returned e-mail addresses of the distribution business sector in the population. The results are shown in Table 2.

Table 1. The resulting parameters of quantitative research

\begin{tabular}{lcccc}
\hline & Private25 & Private25-250 & Private250 & Public \\
\hline Population & 52212 & 17034 & 1468 & 12762 \\
\hline Usable_mail/db & 24300 & 12300 & 739 & 2450 \\
\hline Usable_mail/populace & $46.54 \%$ & $72.21 \%$ & $50.34 \%$ & $19.20 \%$ \\
\hline Summary/db & 24300 & 12300 & 739 & 2450 \\
\hline Random pattern & 2430 & 1230 & 739 & 2450 \\
\hline Pattern/usable_mail & $10.00 \%$ & $10.00 \%$ & $100.00 \%$ & $100.00 \%$ \\
\hline Sent_summary & 2430 & 1230 & 739 & 2450 \\
\hline Reminded & $1 \times$ & $1 \times$ & $2 \times$ & not reminded \\
\hline Returned & 313 & 174 & 194 & 119 \\
\hline Date of execution & $8.7 .2014-$ & $10.11 .2014-$ & $22.4 .2014-$ & $5.1 .2015-$ \\
& 10.11 .2014 & 5.1 .2015 & 8.7 .2014 & 15.2 .2015 \\
\hline Published E-mail returned & 177 & 91 & 130 & 80 \\
\hline Returnability & $\mathbf{1 2 . 8 8 \%}$ & $\mathbf{1 4 . 1 5 \%}$ & $\mathbf{2 6 . 2 5 \%}$ & $\mathbf{4 . 8 6 \%}$ \\
\hline
\end{tabular}

3 The concept of the population (or subpopulation) is used in statistical significance and represents a basic set (or part of it), cf. e.g., Hendl (2006, p. 37) and Veteška (2016b, p. 239). 


\begin{tabular}{lcccc}
\hline & Private25 & Private25-250 & Private250 & Public \\
\hline Use TM & 96 & 51 & 97 & 57 \\
\hline Ratio use TM/returned & $30.67 \%$ & $29.31 \%$ & $50.00 \%$ & $47.90 \%$ \\
\hline
\end{tabular}

Source: Own processing

Note: Private_25 = organizations with less than 25 employees; Private_25-250 = organizations from 25 to 250 employees; Private_250 = organizations with more than 250 employees; Public $=$ public organizations of all sizes; Population $=$ the total number of organizations targeted by the criteria (number of employees); Usable_mail/db = the number of organizations that can be reached from the database (indicated by e-mail); Usable_mail/population = ratio of applicable organizations to population (percentage); Summary/db = total number of useful contacts; Random pattern = selected samples of the population, random $10 \%$ if there is a large population, $100 \%$ for small populations; Pattern/usable_mail $=$ ratio of selected random contacts (percentage); Sent_summary = real number of organizations to which the survey was sent; Reminded = number of reminders during research; Returned $=$ the number of returned useful answers; Date of execution $=$ date of research and its duration; Published E-mail returned = the number of returnees who identified via e-mail; Returnability $=$ percentage ratio of returned answers to the number of those where survey was sent; Use TM = the number of organizations that work with talents; Ratio use TM/returned = proportion of organizations that deal with talent management to returned answers;

Table 2. Verifying the representativeness of the sample - economic entities by business sector (private organizations only)

\begin{tabular}{lccccccc}
\hline \multicolumn{1}{|l}{ Industry group } & Total & $\begin{array}{c}\text { Ratio } \\
\text { total }\end{array}$ & $\begin{array}{c}\text { Returned } \\
\text { total }\end{array}$ & $\begin{array}{c}\text { Total rt } \\
\text { ratio }\end{array}$ & $\begin{array}{c}\text { Popu- } \\
\text { lation } \\
\text { expected }\end{array}$ & $\begin{array}{c}\text { Selection } \\
\text { expected }\end{array}$ & $\begin{array}{c}\text { Chi } \\
\text { square }\end{array}$ \\
\hline $\begin{array}{l}\text { Agriculture, hunt- } \\
\text { ing and forestry }\end{array}$ & 32007 & $4.9 \%$ & 12 & $3.0 \%$ & 3207 & 19.62 & 2.96 \\
\hline $\begin{array}{l}\text { Mining and quar- } \\
\text { rying }\end{array}$ & 142 & $0.2 \%$ & 2 & $0.5 \%$ & 142 & 0.87 & 1.47 \\
\hline Production & 14206 & $21.8 \%$ & 101 & $25.4 \%$ & 14206 & 86.93 & 2.28 \\
\hline $\begin{array}{l}\text { Manufacturing } \\
\text { industry }\end{array}$ & 1417 & $2.2 \%$ & 10 & $2.5 \%$ & 1417 & 8.67 & 0.2 \\
\hline $\begin{array}{l}\text { Production and dis- } \\
\text { tribution of electrici- } \\
\text { ty gas, water, heat }\end{array}$ & 1410 & $2.2 \%$ & 4 & $1.0 \%$ & 1410 & 8.63 & 2.48 \\
\hline Building & 7822 & $12.0 \%$ & 45 & $11.3 \%$ & 7822 & 47.86 & 0.17 \\
\hline Trade & 15275 & $23.5 \%$ & 97 & $24.4 \%$ & 15275 & 93.47 & 0.13 \\
\hline Transport & 3832 & $5.9 \%$ & 10 & $2.5 \%$ & 3832 & 23.45 & 7.71 \\
\hline Services & 16265 & $25.0 \%$ & 109 & $27.4 \%$ & 16265 & 99.53 & 0.90 \\
\hline Other & 418 & $0.6 \%$ & 1 & $0.3 \%$ & 418 & 2.56 & 0.95 \\
\hline Financial services & 832 & $1.3 \%$ & 6 & $1.5 \%$ & 832 & 5.09 & 0.16 \\
\hline
\end{tabular}




\begin{tabular}{lccccccc}
\hline \multicolumn{1}{c}{ Industry group } & Total & $\begin{array}{c}\text { Ratio } \\
\text { total }\end{array}$ & $\begin{array}{c}\text { Returned } \\
\text { total }\end{array}$ & $\begin{array}{c}\text { Total rt } \\
\text { ratio }\end{array}$ & $\begin{array}{c}\text { Popu- } \\
\text { lation } \\
\text { expected }\end{array}$ & $\begin{array}{c}\text { Selection } \\
\text { expected }\end{array}$ & $\begin{array}{c}\text { Chi } \\
\text { square }\end{array}$ \\
\hline $\begin{array}{l}\text { Research and } \\
\text { development }\end{array}$ & 215 & $0.3 \%$ & 1 & $0.3 \%$ & 215 & 1.32 & 0.08 \\
\hline SUMMARY & 65041 & $100.0 \%$ & 398 & $100.0 \%$ & 65041 & 398.00 & 19.50 \\
\hline
\end{tabular}

Source: ČSÚ [Czech Statistical Office - Business subjects by legal form and number of employees (ref: ORG5021UU_KR)] - own processing

Note: Total $=$ the absolute frequency of organizations in the population; Ratio total $=$ relative frequency in the population organizations; Returned total = number of returned answers; Total rt_ratio $=$ relative number of returned answers; Population expected $=$ expected frequency in the population (equal to the absolute); Selection expected = expected frequency in the sample of returned answers; Chi square $=$ partial compliance calculations (Chi-squared test).

\section{Calculation of representativeness of pattern with Chi-squared test}

$$
\begin{aligned}
& \mathrm{n}_{\mathrm{o}}-\text { expected frequency } \\
& \mathrm{n}_{\mathrm{e}}-\text { experimental frequency }
\end{aligned}
$$

Test criteria:

$$
\begin{aligned}
\chi^{2}=\sum \frac{\left(n_{e i-n_{o i}}\right)^{2}}{n_{o i}} & = \\
& =\frac{(12-19.62)^{2}}{19.62}+\frac{(2-0.87)^{2}}{0.87}+\frac{(101-86.93)^{2}}{86.93}+\frac{(10-8.67)^{2}}{8.67}+\frac{(4-8.63)^{2}}{0.87} \\
& +\frac{(45-47.86)^{2}}{0.87}+\frac{(97-93.47)^{2}}{0.87}+\frac{(10-23.45)^{2}}{0.87}+\frac{(109-99.53)^{2}}{0.87}+\frac{(1-2.56)^{2}}{0.87} \\
& +\frac{(6-5.09)^{2}}{0.87}+\frac{(1-1.32)^{2}}{0.87}=19.5
\end{aligned}
$$

Degrees of freedom:

$v=m-1=11$

Critical values corresponding levels $\alpha=0.05$ and $\alpha=0.1$ and given degree of freedom:

$$
\begin{aligned}
& \chi^{2} 0.95(11)=19.677 \\
& \chi^{2} 0.90(11)=17.276
\end{aligned}
$$


We find:

$\chi^{2}<\chi^{2} 0.95(11)=>$ the difference between the measured and expected frequency is not statistically significant at the 0.05 level of significance.

Conclusion: The sample is considered representative, statistically it is not significantly different from the population.

It can be stated that even the representativeness of the returned sample of responses from private organizations is satisfactory, since the distribution of the business sectors in the sample corresponds approximately to the distribution of the sectors of the population. Also, Chi-squared test shows that there is no significant difference in the distribution of sectors in the population and distribution sectors in the organizations. Public organizations are dominantly prevalent in the population schools (unless you count church organizations, municipalities and municipals) $)^{4}$, as well as in our sample of returned answers ${ }^{5}$, but we cannot make a conclusion of the representativeness of public organizations due to the small sample. ${ }^{6}$

4 It also includes associations, endowment funds, foundations, associations (federation, union, society, club, etc.), an organizational unit of the association, an association of legal entities, hunting communities, etc., were not taken into account as a public employee organizations and are not subject to our research.

5 The most important aspect for all quantitative research was to get the questionnaire into the right hands. To secure that the answers were really valid, it was necessary to ensure that the relevant employee is either a human resource staff member dealing with talent management or a member of the management team working with talents or a representative of leadership familiar with this issue. Failure to do so may have caused distortion. This goal was achieved in two ways. The first was the purchase of a professional contact database, verified by other clients, and the second one was the pre-research implementation to verify the above-mentioned aspect of the "right matching, representing the entire organization", confirming the validity of the overall research. A cover letter (e-mail) also put emphasis on this aspect, as well as explaining the importance of representing the entire organization, its goals and talent management programs in response, and not the attitudes and opinions of the evaluator. However, we realized that there might still be distortions affecting the results. These distortions, meanwhile, can only be minimal due to positive and negative effects after averaging all the results. Pre-research, therefore, identified the necessary facts that served as a basis for measures to ensure the validity of the final research.

6 Our database has 2450 usable e-mail contacts, $98 \%$ of which were schools (elementary, middle, high). 


\section{Research Results}

Answers to the hypotheses are presented, including discussions on the connections found.

- H1 $^{7}$ : Methods that are used in organizations most often are also reported to be the most effective ones (connections, cf. Table 3).

The values of the probability of random match are shown in Table 3. The actual matches are visibly larger and it is a recognizably strong association between the use of the most common methods and their highest regarded efficiency. The relationship was proved and we can confirm the hypothesis ${ }^{8}$.

Table 3. Association between the use of the most common and considered the efficiency of methods of talent management by individual processes and the forms and sizes of organizations

\begin{tabular}{|c|c|c|c|c|c|c|c|c|c|c|c|c|}
\hline $\begin{array}{l}\text { organization/ at } \\
\text { least most used- } \\
\text { most effective }\end{array}$ & & dentific & ation ( 9 & & & evelop & nent (\% & & & Reten & ion (\%) & \\
\hline $\begin{array}{l}\text { organization/ } \\
\text { most used-most } \\
\text { effective match }\end{array}$ & all & at least 2 & at least 1 & zero & all & at least & at least 1 & zero & all & at least 2 & at least 1 & zero \\
\hline $\begin{array}{l}\text { small private } \\
\text { organizations }\end{array}$ & 24.0 & 74.0 & 99.0 & 1.0 & 20.8 & 62.5 & 90.6 & 9.4 & 35.4 & 92.7 & 100.0 & 0.0 \\
\hline $\begin{array}{l}\text { middle private } \\
\text { organizations }\end{array}$ & 23.5 & 76.5 & 98.0 & 2.0 & 13.7 & 66.7 & 94.1 & 5.9 & 39.2 & 100.0 & 100.0 & 0.0 \\
\hline $\begin{array}{l}\text { large private } \\
\text { organizations }\end{array}$ & 22.7 & 70.1 & 95.9 & 4.1 & 16.5 & 58.8 & 89.7 & 10.3 & 35.1 & 86.6 & 99.0 & 1.0 \\
\hline $\begin{array}{l}\text { private organiza- } \\
\text { tions total }\end{array}$ & 23.4 & 73.0 & 97.5 & 2.5 & 17.6 & 61.9 & 91.0 & 9.0 & 36.1 & 91.8 & 99.6 & 0.4 \\
\hline $\begin{array}{l}\text { public organiza- } \\
\text { tions }\end{array}$ & 17.5 & 61.4 & 93.0 & 7.0 & 19.3 & 59.6 & 91.2 & 8.8 & 54.4 & 96.5 & 100.0 & 0.0 \\
\hline random match & 0.5 & 12.7 & 61.8 & 38.2 & 0.2 & 8.1 & 51.7 & 48.3 & 5.0 & 50.0 & 95.0 & 5.0 \\
\hline
\end{tabular}

Source: Own processing

7 For each hypothesis, the operationalization of the variables were performed and their values (frequency of responses) compared.

8 Also Chi-squared test showed that there is significant difference between our results and random match. 
Calculation: We assumed that we had a selection from 12 methods for identification, from 15 methods for developing and from 6 methods for keeping talents. First, we selected from each group 3 methods used most often and then again three methods considered to be most effective. If we made this choice randomly, a match would be in different groups with probability $\frac{1}{C(n, 3)}$, where $\mathrm{n}$ is number of methods and $C(n, 3)$ refers to a combination of all three from $n$. A match of at least 2 methods would be with the probability $\frac{1+3 \times(n-3)}{C(n, 3)}$, a match with at least 1 method with the probability $\frac{C(n, 3)-C(n-3,3)}{C(n, 3)}$, no match with the probability $1-\frac{C(n, 3)-C(n-3,3)}{C(n, 3)}$.

- H2: Private organizations consider an interview with experts as a more effective method for identification of talents than public organizations.

This hypothesis cannot be confirmed. Our findings point to the fact that in private organizations the method is used in $36 \%$, in public in $45 \%$. Originally, we assumed that private organizations can afford to pay experts to identify talents and therefore use this method more than public organizations, where there is a problem with funding. However, probably the factor of an abundance of experts in public organizations (such as schools, the teacher is an expert in the field) interfered with our results and therefore paradoxically an interview with an expert is cheaper in public organizations. The hypothesis is, therefore, refuted. Another reason may be the great efficiency of assessment centres in large organizations, where these centres are likely to have an interview with an expert.

- H3: Large private organizations, contrary to small organizations, consider several methods based on individual development (coaching, mentoring, counselling, assistance, job rotation, individual development plan) as the most effective methods of developing talents.

This hypothesis can be confirmed (cf. Table 4). Large private organizations label more often some of the methods on an individual basis between the three most effective methods, as opposed to small private organizations. Small organizations assign greater efficiency to methods of remuneration, valuation, education and special training. Explanations can be derived from the size of the organization again. Thanks to the greater anonymity of large companies, there are greater opportunities of moving and development (vertical and horizontal development) thanks to methods which are, on an individual basis, considered highly effective compared to those in small organizations. Another reason may 
be the fact that in small organizations, because of their size, access to talented employees is regarded as individual (less interaction between people, narrower definition of objectives, etc.). Costs of a purely individual approach may also be high for a small organization. It is also necessary to mention that, e.g., mentoring is used in large organizations to resolve disputes with superiors, which could affect the reported efficiency.

Table 4. The efficiency of methods based on individual development

\begin{tabular}{lcccccc}
\hline $\begin{array}{c}\text { Organ- } \\
\text { ization/ } \\
\text { method }\end{array}$ & Couching & Mentoring & Counseling & Assistance & $\begin{array}{c}\text { Work } \\
\text { rotation }\end{array}$ & $\begin{array}{c}\text { Individual } \\
\text { development } \\
\text { plan }\end{array}$ \\
\hline large & $46 \%$ & $34 \%$ & $0 \%$ & $5 \%$ & $26 \%$ & $53 \%$ \\
\hline small & $30 \%$ & $20 \%$ & $2 \%$ & $14 \%$ & $18 \%$ & $31 \%$ \\
\hline
\end{tabular}

Source: Own processing

- H4: Public organizations consider methods for the retention of talents on the basis of non-financial benefits as more effective than private organizations.

The difference is not so great $-94 \%$ of public, $81 \%$ private, but detectable. So the hypothesis can be confirmed. The explanation is the inability of public organizations to use multiple financial valuation (lack of funds), and less anonymity in public organizations and perhaps even force of non-financial rewards for social prestige in the public sector.

- H5: With the larger size of private organizations, the indicated efficiency of financial valuation decreases.

We can confirm the hypothesis. A downward trend is evident. Large private organizations consider the financial valuation as the most efficient in 59\%, moderate in $71 \%$ and small in $77 \%$. For public organizations, on the contrary, financial valuation is considered as the most effective in the entire $94 \%$. The considered large efficiency of financial valuation for public organizations is likely due to the lower nominal salary value of its employees, which is why many of them go to the private sphere and therefore valuation is very effective to retain such individuals. On the contrary, in large private organizations talented people deserve to be paid well, the company realizes their importance and thus valuing is not the most effective technique. To keep talented employees requires 
a more sophisticated approach, combining multiple methods and differentiation of competition.

\section{Answers to our research questions}

Let us review our goals we set at the beginning of this study. All the research questions related to the research problem $\mathrm{P}$ - the perceived (considered) efficiency of methods of talent management in different types and sizes of organizations.

- Q1: What methods do organizations consider as effective? (large-small, private-public) (related hypothesis: $\mathrm{H} 1$ ).

The most effective seem to be methods that are also most frequently used. When organizations consider methods that they often use themselves as effective methods, we can say that the selection of methods does not encounter any obstacles or lack of resources, but organizations choose methods proven to be efficient. Otherwise, there would have to be a very weak correlation between the reported efficiency and the most frequently used methods.

- Q2: Which methods are, according to organizations, most efficient for the identification of talents? (large-small, private-public) (related hypothesis: $\mathrm{H} 2$ ).

The methods considered most effective for identifying talented employees are presented in Table 5. Special assignment and evaluation are considered the most effective methods for identifying talents. For private organizations, they also precede the interview with an expert method.

- Q3: Which methods are, according to organizations, most efficient for the development of talents? (large-small, private-public) (related hypothesis: H3).

The methods considered most effective for developing talents are shown in Table 5. Education and training play the most important role in the development of talents and are considered the most effective method. For large private organizations, however, they come to the fore as methods based on individual development (coaching, mentoring, job rotation, individual development plan). 
- Q4: Which methods are, according to organizations, most efficient for the retention of talents? (large-small, private-public), (related hypothesis: $\mathbf{H 4}$, H5).

The method considered most effective for retaining talents are presented in Table 5. There are non-financial rewards and financial valuation. For public organizations, what is primarily used is non-financial remuneration, compared to private organizations. Especially in large private organizations, the efficiency of financial and non-financial reward valuation increases, to the detriment of the efficiency of methods of individual development (career growth, special development programs).

Table 5. Three methods considered most effective in organizations

\begin{tabular}{|c|c|c|c|c|}
\hline $\begin{array}{c}\text { Cosidered } \\
\text { most effective } \\
\text { methods }\end{array}$ & Small organizations & Middle organizations & Large organizations & Public organizations \\
\hline Identification & $\begin{array}{l}\text { Special task } \\
\text { Comparison of needed } \\
\text { improvement in time } \\
\text { Ongoing evaluation }\end{array}$ & $\begin{array}{l}\text { Ongoing evaluation } \\
\text { Special task } \\
\text { Comparison of needed } \\
\text { improvement in time }\end{array}$ & $\begin{array}{l}\text { Ongoing evaluation } \\
\text { Spiecial task } \\
\text { Review with expert in } \\
\text { target area }\end{array}$ & $\begin{array}{l}\text { Spiecial task } \\
\text { Ongoing evaluation } \\
\text { Review with expert in } \\
\text { target area }\end{array}$ \\
\hline Development & $\begin{array}{l}\text { Special training } \\
\text { Remuneration (non } \\
\text { financial) } \\
\text { Edcation within organ- } \\
\text { ization }\end{array}$ & $\begin{array}{l}\text { Special training Educa- } \\
\text { tion within organization } \\
\text { Individual personal } \\
\text { development }\end{array}$ & $\begin{array}{l}\text { Individual personal } \\
\text { development Special } \\
\text { Traing Couching }\end{array}$ & $\begin{array}{l}\text { Remuneration (non } \\
\text { financial) } \\
\text { Valuation (finacial) } \\
\text { Special training }\end{array}$ \\
\hline Retention & $\begin{array}{l}\text { Remuneration (non } \\
\text { financial) } \\
\text { Valuation (financial) } \\
\text { Individual personal } \\
\text { development }\end{array}$ & $\begin{array}{l}\text { Individual personal } \\
\text { development } \\
\text { Remuneration (non } \\
\text { financial) } \\
\text { Valuation (finacial) }\end{array}$ & $\begin{array}{l}\text { Individual personal } \\
\text { development } \\
\text { Remuneration (non } \\
\text { financial) } \\
\text { Valuation (finacial) }\end{array}$ & $\begin{array}{l}\text { Remuneration (non } \\
\text { financial) } \\
\text { Valuation (finacial) } \\
\text { Individual personal } \\
\text { development }\end{array}$ \\
\hline
\end{tabular}

Source: Own processing

- Q5: Is the efficiency of talent management measured? (large-small, private-public).

The efficiency of methods of talent management is measured only in a small proportion of organizations working with talented employees. It amounts to about $25 \%$ of private organizations and $11 \%$ of public organizations. If organizations use talent management, then they do not usually have any instructions or recommendations on how to measure the efficiency of its methods. We found that organizations consider the most commonly used methods as effective as possible. A relationship has been demonstrated between frequent use and deemed efficiency. We did not find special ways of measuring and most organizations do not measure efficiency or do not know how to measure it. However, even with the organizations 
that have indicated that efficiency measures were highly questionable outlined metrics and only in some cases were reliable and valid.

\section{Other Conclusions}

- The method considered most effective for identifying talents is ongoing evaluation and special assignment. Based on theoretical assumptions, assessment centres should be considered as the most effective, but they are not. The cause is likely to be the financial difficulty of using assessment centres by some organizations.

- The method considered most effective in developing talent is continuing education and special training. Allowing further education plays a significant role in developing talent. Education is seen as the most effective method for developing talents in all scales of private and public organizations.

- The method considered most effective for keeping (retaining) talents is rewarding and valuation. This is hardly surprising, but it has been shown that the size of private organizations decreases the importance of rewarding and valuing and also other methods come to the fore. The explanation can be derived from the size of the organization. Thanks to the greater anonymity of large companies, greater opportunities to move (vertical and horizontal development) in large companies are the methods considered very effective on an individual basis, compared to small organizations. Another reason may be the fact that in small organization, access to talented employees is considered "individual" (less interaction between people, narrower definition of objectives, etc.). Costs of a purely individual approach may also be high for a small organization. It should also be noted that, e.g., mentoring is used in large organizations to resolve disputes with the direct superior, which could affect the reported efficiency.

- Efficiency of the methods is measured very rarely, they are not compared with each other, but rather against the existence and absence of the use of each method. Organizations are not able to compare the efficiency of several methods of talent management under ceteris paribus. Comparison of the efficiency of methods is demanding and when organizations compare the efficiency of the methods, it is more about intuition and long experience than an exact process. 
- Where the efficiency of methods is measured, it is always in the context of a specific organization, but without isolation of other variables (e.g., a random factor, the number of proposals for improvement efficiency of algorithms, etc.). As indicated in the study, organizations that reported that they measure efficiency, use some simple indicators to determine the efficiency of talent management methods.

- There is no universal metric measuring the efficiency of the methods of talent management, but organizations using talent management implement different talent management metrics, processes, ways to demonstrate the benefits of talent management. There is demand for possibilities and ways of measuring the efficiency of methods of talent management and therefore it can be assumed that they will increase over time, together with the increasing implementation of talent management programs in organizations.

- Smaller private and public organizations work with talented employees more intuitively, less systematically and less formally, but certainly talents are supported using available and known methods for their identification, development and retention, like in large organizations. Research has shown that the methods used in various large organizations are not fundamentally different, although there are differences in the assumed efficiency and frequency of use of methods, but even these differences are very small.

\section{References:}

Hatum, A. (2010). Next Generation Talent Management: Talent Management to Survive Turmoil. New York: Palgrave Macmillan.

Hendl, J. (2006). Přehled statistických metod zpracování dat. (Overview of statistical data processing methods). Praha: Portál.

Khoreva, V., Vaiman, V., \& Van Zalk, M. (2017). Talent management practice effectiveness: investigating employee perspective. Employee Relations, 39(1), 19-33. DOI: 10.1108/ ER-01-2016-0005.

Kursch, M., (2016). Tailor Made Talent Management - Second-generation Talent Management. Praha: Česká andragogická společnost.

Lewis, R.E., \& Heckman, R.J. (2006). Talent management: A critical review. Human Resource Management Review, 16(2), 139-154. DOI: 10.1016/j.hrmr.2006.03.001.

McDonnell, A., Collings, D.G., Mellahi, K., \& Schuler, R. (2017). Talent management: A systematic review and future prospects. European Journal of International Management, 11(1), 86-128. DOI: 10.1504/EJIM.2017.081253.

Schiemann, W.A. (2009). Reinventing Talent Management: How to Maximize Performance in the New Marketplace. Hoboken, New Jersey: John Wiley \& Sons. 
Sparrow, P., Scullion, H., \& Tarique I. (2014). Introduction: challenges for the field of strategic talent management. In Sparrow, P., Scullion, H., \& Tarique, I. (eds.) Strategic Talent Management: Contemporary Issues in International Context. St. Ives: Cambridge University Press, $1-35$.

Swailes, S. (2016). The Cultural Evolution of Talent Management: A Memetic Analysis. Human Resource Development Review, 15(3), 340-358. DOI: 10.1177/15344 84316664812.

Veteška, J. (2016). Přehled andragogiky: úvod do studia vzdělávání a učení se dospělých. (Overview of Andragogy: An Introduction to Adult Education and Learning). Praha: Portál. 